\title{
Employees'Association in Police Department With Reference to Khammam District, Telangana State.
}

\author{
Dr. Venkata Rama Murthy Kambhampati ${ }^{1,}$ Dr. Satyanarayana Thota ${ }^{2}$ \\ ${ }^{I}$ Associate Professor and HOD of MBA Mother Teresa Institute of Science and Technology Sanketika Nagar, \\ Sathupally -507303, Khammam Dist.,Telangana \\ ${ }^{2}$ Associate ProfessorSt.Marys Women's Engineering CollegeBudamapadu,Guntur
}

\begin{abstract}
Police are a standout amongst the most ubiquitous associations of the society. Police Department is one of the vital department for societal wellbeing. Police need to work round the clock to keep open safe. The Employees' relations are vital in job fulfillment and work environment of any organization. Employees' relationship decides conduct in terms of inspiration, correspondence and level of responsibility which me vital in technique execution in any association. The goal of this exploration is to exam the employees' relationship of police in khammam district police stations furthermore to know how the relationship impact the occupation fulfillment of employees, give suitable suggestions to beat the issues for all intents and purposes develops in the relationship of police employees. The research design undertaken for the study was descriptive research and convenience sampling method is used and the sample size consist of 268 respondents. Simple percentage method, descriptive statistics and chi-square analysis was used to analyze the data collected and results of the study states that the there is an influence of employees relation on job satisfaction.
\end{abstract}

Keywords: Employee Association, Khammam, Police, Job satisfaction JEL Classification:- M00, M5 and M5

\section{Introduction}

Human Resource Management as a discipline is responsible for identifying, selecting, inducing the competent people, training them, facilitating and monitoring them to perform with high level of efficiency and thereby providing them a mechanism to ensure that they maintain a strong affiliation with their organization. All organizations, be they private or government organizations are basically Social systems run by people having expertise in relevant fields. Thus, human resources constitute the entire work force of an organization.The Functioning of an organization depends on how its employees work. HRM is of utmost importance for Police as Police job can be dangerous, frustrating, even tedious, but law enforcement is a tremendously rewarding career. Police officers significantly improve the quality of life for the citizens of their communities by keeping the peace despite sometimes overwhelming odds. The police personnel, who are qualified, well trained, best motivated and led by competent superiors, always contribute towards the improvement in work culture. The areas covered by HRM in police department include recruitment and selection, training, transfers and promotions, leadership, communication, authority and responsibility, motivation and incentives, SuperiorSubordinate relationships, compensation management, performance appraisal etc. HRM is very important in police organization because police works as a visible symbol of the government. Human management in Police is complex and demanding because it involves the management of the policemen both on and off duty from the day they enter the organization. The essence of a dynamic personnel management is getting effective and optimum results not only on short term basis but also in the long run through building and maintaining a satisfied, motivated and productive human organization. Police being a non-development department get a second-rate treatment in the financial allocation. The police department therefore should be included in the list of 'plan' departments, so that it may get due priority in the financial allocation for modernizing itself in terms of men, money, material, machines and methods. A modernized police organization will become progressive in their functioning and democratic in their behavior.

\section{Significance of the Study}

Quotation by August Vallmore "The policeman is denounced by public, criticized by preacher, ridiculed by the movies, berated by newspapers and unsupported by the prosecuting officers and judges. He is shunned by the respectable, condemned while he enforces the law and dismissed when he does not. He is supposed to possess qualifications of a soldier, doctor, lawyer, diplomat and educator, while the facilities, employees' relationship at work environment etc., not better when compare with other professions .'This quotation speaks about the plight of police in general and the urgent need to redress their grievances and improve public -police partnership.

\section{Police History}

The police in India are as old as the nation herself. Ancient India saw police as an instrument under the kings. They were ministers or important individuals who were vested with police functions. The Moghul period 
some kind of organized patterns set into the police system. However there were glaring differences between systems of policing from one state to another which was noticed by the British. Realizing the need for a unified policing system in India, the British by a process of experimentation evolved the existing pattern of Police that was embodied in the Indian Police Act, Act-V of 1861. Modeled on the pattern of the army, the police personnel are to be utilized mainly for quelling disturbances by the civil population. This system has been the basis for the formation and functioning of all police systems in India that are constantly waging a war against internal enemies.

The T.S. Police came into existence along with the formation of Telangana State. Some parts of the present Telangana state was ruled by the Asaf Jah dynasty. The organization of the police during this period was called the Kaveli System or the Hindoo Police. In each village, town, city and district were stationed officers of police with gradations of rank and numbers of retainers commensurate with their ranges, from that of the humblest Kavilgar to the most powerful Poligar. The Kavilgars were entrusted the internal security and tranquility of the state. They were armed and paid by means of contributions from every inhabitant in addition to an assessment amount. The Poligars were expected to join the king's army in times of external danger. They were entrusted with the safety of public property and were armed with the means and paid for the purpose of protecting it. They were held responsible and questioned for all thefts, robberies, depredation, detection and apprehension of public offenders. When the British came in the 19th century they introduced a system of policing that initiated a process of transition from military diplomacy to a modernized system.

The Police Act 1861 instituted the system of policing which is in force in India today. It is Act V that regulates the organization, recruitment and discipline of the India Police. With the induction of the Police Code in 1865 and the creation of the post of Inspector General of Police, there was a marked improvement in the law and order scenario in the country.

Figure 1: The Field Establishment of the Police Force Director General of Police (DGP) \{ In-charge of the State Police Force $\downarrow$

Additional Director General of Police (Addl. DGP)

$\downarrow$

Inspector General of Police (IGP) \{In-charge of a zone, which comprises few ranges

$\downarrow$

Deputy Inspector General of Police (Dy. IGP) \{In-charge of a range, which comprise a group of districts $\}$

$\downarrow$

Senior Superintendent of Police (SSP) \{In-charge of the bigger District\}

$\downarrow$

Superintendent of police (SP) \{In-charge of the District $\}$

$\downarrow$

Additional Superintendent of Police (Addl. SP)

$\downarrow$

Assistant/ Deputy Superintendent of Police (ASP/Dy. SP) \{In-charge of a Sub-division in the district $\}$

$\downarrow$

Inspector of Police $\{$ In-charge of a Police Station $\}$

$\downarrow$

Sub-Inspector of Police (SI) \{In-charge of a smaller Police Station $\}$

$\downarrow$

Assistant Sub-Inspector of Police (ASI) \{Staff of the Police Station $\}$

$\downarrow$

Police Head Constable (HC) \{Staff of the Police

Station $\}$

$\downarrow$

Police Constable \{Staff of Police Station

Source: http://www.tspolice.gov.in

\section{Employees' Relationship}

The morning parade and salute to the commandant officer, the armed sentry at the superintendent gate and armed escort on the tour were symbols that placed the superiors on a high pedestal. This style of governance created a cultural setting in which the administrators were way above those bossy ruled and the distance was deliberately maintained. The subordinate officers were encouraged to assert their authority and perhaps their extortions were seen as a way to restrain the people. The cultist nature of the senior rank (Superiors) is visible not only in the common form of gatherings where subordinate salute and come to attention before senior officers 
but also in their interaction. Constables and even middle level officers do not sit down in front of the superintendent. IPS officers still employ constables as personal orderlies who supply as servants of the officer. Office vehicles, telephone and staff are used for personal purposes. Subordinate officers escort the children to school or the spouse for shopping and making social visits.

Similarly subordinate officers are routinely utilized for making purchase and for making arrangements during private parties and functions. Thus there is a misuse of human resources. They have little legitimacy and moral strength to take a firm action against the extortions indulged by their officers. The police agitations clearly betrayed a lack of relationship between the superiors and subordinate in their forces. There is a growing feeling among the rank and file that the senior officers are neither able to protect them from unwarranted attacks from political and other quarters, nor effective in getting their legal governances redressed by government or appropriate authority. The importance of controlling situational discretion, constructing relevant data sets and changing cultural in doctrinarian that creates gap between the superiors and the subordinates.

\section{Leadership in the Police Department}

The leadership role assumes great significance in all organization because without leadership, an organization is but a muddle of men and machines. The essence of leadership is the ability to obtain from each member of the organization, the highest quality of service he has the capacity to render. Leadership can be defined as the process of influencing the behaviour of others to work willingly and enthusiastically for achieving pre-determined goals. Good leadership in the organization itself is the motivating factor for any organization.

A successful police leader will be able to promote internal cohesion by emphasizing before his subordinates the goals of the organization and at the same time, treating them like human beings by recognizing and fulfilling their individual needs. In the context of police organization, leadership is the process of influencing organizational member to use their energies willingly and appropriately to facilitate the attainment of goals set up by the police organization.

The police leader should be tough, but sincere, accomplished but basic, formal but approachable, informal but strong, suspicious but empathetic, authoritarian but flexible, democratic but management oriented, physical bearing, moral courage, decisiveness, dependability, endurance, enthusiasm, initiative, integrity, judgment, justice, knowledge, loyalty and unselfishness are considered as essential traits of successful police leadership. Thus, the issue of police leadership itself needs to be addressed in the context of restructuring the entire police force and re-institutionalizing of effective leadership from with the organization based on the principles of professionalism, democratic value system, autonomy, management skills and commitment to public section.

\section{Literature Review}

Marwah, in his article has commented on human resource practices in police. As per his expert observations, the biggest resource the police department has is the human resources. Subordinate ranks are the cutting edge in the police department. It is mostly they who interact with the people. Their seniors should not neglect them. They should look after them and listen to them. The growing distance between junior ranks need to be reduced. They are a storehouse of information and are gifted with shrewdness. A well knit team can do wonders. Some are good at investigations and others in law and order duties. It is important to discriminate and make use of them according to their capabilities. He has accepted the fact that he himself has learnt more from juniors than from seniors. He believes that if one earns their respect and trust, this can be an invaluable asset. Sen expresses his views saying that in our country, an important factor responsible for episodic outbursts of police violence and brutality is the deplorable conditions under which police works. The hours of duties are long and irregular of all government agencies, the housing conditions are the worst.

According to Herzberg (1959), different factors combine to create job satisfaction and dissatisfaction among employee. He identified these as either motivators or hygiene factors. Motivators promote job satisfaction. They include: (a) achievement, (b) responsibility, (c) the work itself, (d) recognition, and (e) advancement/promotion. Hygiene factors do not directly lead to job satisfaction among employees. However, their absence may lead to job dissatisfaction. They consist of: (a) organizational policies, (b) supervision and leadership, (c) pay or salary, (d) work conditions, (e) communication with supervisors/work partners. Herzberg contended that employees need to reach an acceptable level of hygiene factors to feel neutral about their jobs. Therefore, employers should seek ways of eliminating dissatisfaction resulting from hygiene factors and focus on improving the motivators in the work environment to increase job satisfaction. Zhao and his colleagues (1999: 154) stated that Herzberg's (1968) two-factor theory of job satisfaction "provides a useful theoretical framework for empirically assessing officers' job satisfaction." They further suggested that a comprehensive examination of job satisfaction not only should cover organizational (work environment) variables but also certain job characteristics and employees' demographic characteristics. 
These organizational variables have had differing impacts upon police job satisfaction. Slovak (1978) found that work satisfaction among police officers was multidimensional and was mostly determined by: (a) equipment/preparation, (b) compensation /advancement, and (c) management/organization. Dantzker and Surrette (1996) determined that the police officers were least satisfied with pay and availability of in-service training but they were most satisfied with their present assignment and immediate supervisor support. Dantzker (1997) reported that organizational size had an impact on police officer job satisfaction. Police officers from agencies that employed less than 100 sworn officers had the highest job satisfaction levels among the three groups of agencies. Police officers from agencies that employed more than 500 sworn officers had the lowest job satisfaction levels among the three groups of agencies. Brunetto and Farr-Wharton (2002) found that pay, dealing with clientele and organizational management practices (promotion, appraisal, and other procedures) decreased police officer job satisfaction. Howard, Donofrio and Boles (2004) reported that work-family conflict was a strong predictor of different aspects of police job satisfaction.

\section{Objectives of The Study}

1. To examine the employees' relationship in police department.

2. To know how far employees' relationship effects the job satisfaction.

3. To study the other HRD climate factors in the police department.

\section{Research Tool}

The present study used the questionnaire as tool for data collection because of its numerous advantages and its ability to yield the most satisfactory range of reliable data. Questionnaires are most suitable in a quantitative study such as the present one. The researcher designed questionnaire in the local language so that the police employee can easily understand and give correct response and collected the secondary data from organization website; publications of the organization, annual reports and journals released by the organizations, office records etc.

Chi-Square Test: Chi-square test enables the researcher to find out whether the divergence between expected and actual frequencies is significant or not. The following formula can be used for calculating chi-square value.

\section{O \\ Ch-Square Test $=\quad-$ \\ Ei}

Where, O- Observed Frequency

E- Expected Frequency

Simple Percentage Analysis: Simple percentage method refers to specified kind which is used in making comparison between two or more series of data. Percentages are based on descriptive relationship. It compares the relative items. Since the percentage reduces everything to a common base and thereby allow meaning comparison. The following formula can be used for calculating percentage.

\section{No. of respondents}

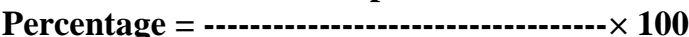

\section{Total no. of respondents}

Table 1:- Socio Economic Factors of Police Employees

\begin{tabular}{|c|c|c|c|c|}
\hline S.No & \multicolumn{2}{|l|}{ Demographic Factors } & $\begin{array}{l}\text { No. of } \\
\text { Respondents }\end{array}$ & $\%$ \\
\hline \multirow[t]{3}{*}{1.} & \multirow[t]{3}{*}{ Gender } & Male & 254 & 94.77 \\
\hline & & Female & 14 & 5.23 \\
\hline & & Total & 268 & 100 \\
\hline \multirow[t]{4}{*}{2.} & \multirow[t]{4}{*}{ Age } & $18-28$ years & 150 & 55.9 \\
\hline & & $28-38$ years & 90 & 33.5 \\
\hline & & $38-48$ years & 28 & 10.6 \\
\hline & & Total & 268 & 100 \\
\hline \multirow[t]{6}{*}{3.} & \multirow[t]{6}{*}{ Educational Qualification } & Others & 8 & 3 \\
\hline & & PG & 39 & 14 \\
\hline & & UG & 104 & 39 \\
\hline & & Inter & 78 & 29 \\
\hline & & SSC & 39 & 15 \\
\hline & & Total & 268 & 100 \\
\hline \multirow[t]{3}{*}{4.} & \multirow[t]{3}{*}{ Regional wise Respondents } & Kothagudam & 44 & 16.41 \\
\hline & & Khammam & 52 & 19.42 \\
\hline & & Dammapeta & 24 & 8.95 \\
\hline
\end{tabular}




\begin{tabular}{|l|l|l|l|l|}
\hline \multirow{4}{*}{} & Badhrachalam & 48 & 17.91 \\
\cline { 2 - 5 } & Kalluru & 12 & 4.47 \\
\cline { 2 - 4 } & Sathupally & 52 & 19.42 \\
\cline { 2 - 4 } & Aswaraopata & 10 & 3.73 \\
\cline { 2 - 4 } & V.M.Banjra & 18 & 6.71 \\
\cline { 2 - 4 } & Vemsoor & 08 & 2.98 \\
\cline { 2 - 4 } & Total & $\mathbf{2 6 8}$ & $\mathbf{1 0 0}$ \\
\hline
\end{tabular}

Source: Primary Data

From the above table the researcher finds that female respondents are less in total sample selected $(14 \%)$. It is identified that most of the respondents are in age group of 18-28 years from this it is notified that their happen a huge recruitment few years back. Most of the police personnel are UG qualified. High numbers of the respondents are belonging to Khammam town and least number belongs to Vemsoor region.

Table 2:- Regional Wise Respondents of Police Employees

\begin{tabular}{|l|l|l|l|l|l|l|l|l|l|l|}
\hline S.No. & Regional & PC & HC & WPC & WHC & ASI & SI & CI & DSP & Total \\
\hline 1 & Khammam & 30 & 04 & 00 & 04 & 04 & 06 & 04 & 00 & 52 \\
\hline 2 & Kothagudam & 26 & 04 & 02 & 00 & 06 & 04 & 02 & 00 & 44 \\
\hline 3 & Bhadrachalam & 30 & 06 & 02 & 02 & 02 & 04 & 02 & 00 & 48 \\
\hline 4 & Sathupally & 28 & 08 & 04 & 02 & 06 & 00 & 02 & 02 & 52 \\
\hline 5 & Dammapeta & 18 & 04 & 00 & 00 & 00 & 02 & 00 & 00 & 24 \\
\hline 6 & Kalluru & 08 & 00 & 00 & 00 & 02 & 02 & 00 & 00 & 12 \\
\hline 7 & Aswaraopet & 08 & 00 & 00 & 00 & 00 & 02 & 00 & 00 & 10 \\
\hline 8 & V.M.Banjra & 16 & 00 & 00 & 00 & 00 & 02 & 00 & 00 & 18 \\
\hline 9 & Vemsoor & 02 & 02 & 02 & 00 & 00 & 02 & 00 & 00 & 08 \\
\hline TOTAL
\end{tabular}

Source: Primary Data

Table 3:- Descriptive Statistics Based on Age Factor

\begin{tabular}{|c|c|c|c|c|}
\hline S.No. & Designation & Age & Mean & Standard Deviation \\
\hline \multirow[t]{3}{*}{1} & \multirow[t]{3}{*}{ Police Constable } & $18-28$ years & 8.4 & 6.06 \\
\hline & & $28-38$ years & 12.8 & 4.83 \\
\hline & & $38-48$ years & 11.2 & 4.96 \\
\hline \multirow[t]{3}{*}{2} & \multirow[t]{3}{*}{ Circle Inspector } & $28-38$ years & 0.4 & 0.8 \\
\hline & & $38-48$ years & 1.2 & 01 \\
\hline & & $48-58$ years & 0.4 & 0.8 \\
\hline \multirow[t]{2}{*}{3} & \multirow[t]{2}{*}{ Women Police Constable } & 18-28 years & 1.6 & 1.497 \\
\hline & & $28-38$ years & 0.4 & 0.8 \\
\hline \multirow[t]{2}{*}{4} & \multirow[t]{2}{*}{ Women Head Constable } & 28-38 years & 0.8 & 1.6 \\
\hline & & $38-48$ years & 1.2 & 1.6 \\
\hline \multirow[t]{3}{*}{5} & \multirow[t]{3}{*}{ Sub Inspector } & $28-38$ years & 04 & 2.83 \\
\hline & & $38-48$ years & 0.4 & 0.8 \\
\hline & & $48-58$ years & 0.4 & 0.8 \\
\hline \multirow[t]{2}{*}{6} & \multirow[t]{2}{*}{ Head Constable } & $38-48$ years & 4.4 & 2.33 \\
\hline & & $48-58$ years & 1.6 & 1.497 \\
\hline
\end{tabular}

Source: Primary Data

\section{Limitation of the Study}

Any research have some limitations by which certain unavoidable circumstances for example time factor, respondent's attitude, their interest, cost, give the data confidently etc. these all factor affect the research study. Different research has their own limitations in this research the limitations are as follow:

The time taken for completion of the research is not adequate. So it is not possible to conduct the depths analysis.

1. The response given by the employees may not correct due of subject favoritism and unfairness of the people involved.

2. The study was conducted in Khamamam district in selected police stations, which may not give the exact picture of the situation.

Hypothesis:

$\mathbf{H}_{\mathbf{0}}$ : - There is no significant association in between relationship among police employees and job satisfaction.

$\mathbf{H}_{\mathbf{1}}$ : - There is a significant association in between relationship among police employees and job satisfaction.

Table 4:- Chi-Square Test based on Age (Police Constable)

\begin{tabular}{|l|l|l|l|l|l|}
\hline S.NO & QUESTION.NO & D.F & C.V & TV & HYPTS \\
\hline 1 & $\begin{array}{l}\text { The top management of Police goes out its way to ensure that the police } \\
\text { personnel enjoy their work }\end{array}$ & 12 & 12.54286 & 21.026 & $\mathbf{H}_{1}$ \\
\hline
\end{tabular}




\begin{tabular}{|c|c|c|c|c|c|}
\hline 2 & $\begin{array}{l}\text { The top management believes that people of police system are extremely } \\
\text { important and they should be treated more humanly }\end{array}$ & 12 & 7.516911 & 21.026 & $\mathbf{H}_{1}$ \\
\hline 3 & $\begin{array}{l}\text { Developing subordinates is considered as important part of their job by } \\
\text { the top management in Police }\end{array}$ & 12 & 12.45688 & 21.026 & $\mathbf{H}_{\mathbf{1}}$ \\
\hline 4 & The personnel policies are helpful to the human development in Police & 12 & 8.814609 & 21.026 & $\mathbf{H}_{1}$ \\
\hline 5 & $\begin{array}{l}\text { The top management is willing to invest time and other resources to } \\
\text { ensure the development of the Police personnel }\end{array}$ & 12 & 6.107434 & 21.026 & $\mathbf{H}_{1}$ \\
\hline 6 & $\begin{array}{l}\text { The senior officers guide the juniors with interest to help them in their } \\
\text { jobs in Police System }\end{array}$ & 12 & 9.467837 & 21.026 & $\mathbf{H}_{\mathbf{1}}$ \\
\hline 7 & $\begin{array}{l}\text { The personnel lacking competence are helped to gain competence by the } \\
\text { senior and experienced people }\end{array}$ & 12 & 4.215462 & 21.026 & $\mathbf{H}_{1}$ \\
\hline 8 & $\begin{array}{l}\text { The top executive believes that the behavior of police Personnel can be } \\
\text { changed and can be helped to develop at any stage in their life }\end{array}$ & 12 & 21.18387 & 21.026 & $\mathbf{H}_{\mathbf{0}}$ \\
\hline 9 & people in Police are helpful to each other & 12 & 3.698363 & 21.026 & $\mathbf{H}_{1}$ \\
\hline 10 & Junior Police people are very informal with their superiors & 12 & 15.0792 & 21.026 & $\mathrm{H}_{1}$ \\
\hline 11 & $\begin{array}{l}\text { The junior people in Police discuss their personal problems with the } \\
\text { senior officers and seek guidance for solving them }\end{array}$ & 12 & 12.72645 & 21.026 & $\mathbf{H}_{1}$ \\
\hline 12 & $\begin{array}{l}\text { Human relations in Police are so good that any personnel wanting to } \\
\text { acquire new knowledge and skill can do it }\end{array}$ & 12 & 16.49716 & 21.026 & $\mathbf{H}_{1}$ \\
\hline 13 & $\begin{array}{l}\text { Seniors guide their juniors to prepare for their higher official } \\
\text { responsibilities }\end{array}$ & 12 & 4.177505 & 21.026 & $\mathbf{H}_{1}$ \\
\hline 14 & $\begin{array}{l}\text { The top executive scouts (searches for) for talent in the juniors and } \\
\text { identify that and develop }\end{array}$ & 12 & 28.44715 & 21.026 & $\mathbf{H}_{\mathbf{0}}$ \\
\hline 15 & $\begin{array}{l}\text { Promotion in the organization is based on suitability of the person than on } \\
\text { favoritism }\end{array}$ & 12 & 9.101889 & 21.026 & $\mathbf{H}_{\mathbf{1}}$ \\
\hline 16 & Good work is rewarded in this organization through incentives & 12 & 7.841345 & 21.026 & $\mathbf{H}_{1}$ \\
\hline 17 & Good work is always observed and special care is taken to appreciate it & 12 & 11.49265 & 21.026 & $\mathrm{H}_{1}$ \\
\hline 18 & $\begin{array}{l}\text { Performance appraisal or confidential reports are based on objective and } \\
\text { full information and not based on favoritism }\end{array}$ & 12 & 9.657908 & 21.026 & $\mathbf{H}_{1}$ \\
\hline 19 & $\begin{array}{l}\text { People in this police system do not have fixed mental impression about } \\
\text { each other }\end{array}$ & 12 & 11.24596 & 21.026 & $\mathbf{H}_{1}$ \\
\hline 20 & $\begin{array}{l}\text { The police people are encouraged to experiment with new ideas and try } \\
\text { out creative methods }\end{array}$ & 12 & 12.67451 & 21.026 & $\mathbf{H}_{1}$ \\
\hline 21 & $\begin{array}{l}\text { Mistakes made by the police is corrected and not punished by top } \\
\text { management }\end{array}$ & 12 & 11.7072 & 21.026 & $\mathbf{H}_{\mathbf{1}}$ \\
\hline 22 & $\begin{array}{l}\text { The mistakes and weaknesses are communicated to the juniors by the } \\
\text { seniors in a polite and non-threatening way }\end{array}$ & 12 & 15.24716 & 21.026 & $\mathbf{H}_{1}$ \\
\hline 23 & $\begin{array}{l}\text { The police personnel are given feedback for future correction and } \\
\text { development }\end{array}$ & 12 & 13.51931 & 21.026 & $\mathbf{H}_{\mathbf{1}}$ \\
\hline 24 & $\begin{array}{l}\text { The personnel in police take efforts to find out their strengths and } \\
\text { weaknesses from their supervising officers and colleagues }\end{array}$ & 12 & 9.583623 & 21.026 & $\mathbf{H}_{1}$ \\
\hline 25 & The training is taken seriously by the Police and they learn from it & 12 & 8.45038 & 21.026 & $\mathbf{H}_{1}$ \\
\hline 26 & The trained personnel are given opportunities to practice their learning & 12 & 6.361941 & 21.026 & $\mathbf{H}_{1}$ \\
\hline 27 & Training is imparted based on genuine training needs & 12 & 22.02365 & 21.026 & $\mathbf{H}_{\mathbf{0}}$ \\
\hline 28 & People trust each other in this organization. & 12 & 17.02335 & 21.026 & $\mathbf{H}_{1}$ \\
\hline 29 & $\begin{array}{l}\text { The junior police personnel are not afraid to discuss or express their } \\
\text { feelings with their superiors }\end{array}$ & 12 & 13.6984 & 21.026 & $\mathbf{H}_{1}$ \\
\hline 30 & $\begin{array}{l}\text { The personnel do express and discuss their feelings with the subordinates } \\
\text { and peers (colleagues) }\end{array}$ & 12 & 11.44781 & 21.026 & $\mathbf{H}_{\mathbf{1}}$ \\
\hline 31 & $\begin{array}{l}\text { The police personnel are encouraged to take decisions and initiatives in } \\
\text { their own sphere without waiting for instructions from seniors }\end{array}$ & 12 & 7.722125 & 21.026 & $\mathrm{H}_{1}$ \\
\hline 32 & $\begin{array}{l}\text { Delegation of authority to encourage juniors to develop handling higher } \\
\text { responsibilities is quite common in this organization }\end{array}$ & 12 & 6.40384 & 21.026 & $\mathbf{H}_{1}$ \\
\hline 33 & $\begin{array}{l}\text { When seniors delegate authority to juniors, the juniors consider it as an } \\
\text { opportunity for development }\end{array}$ & 12 & 4.40207 & 21.026 & $\mathrm{H}_{1}$ \\
\hline 34 & Team spirit is very high in this organization & 12 & 12.51398 & 21.026 & \\
\hline 35 & $\begin{array}{l}\text { Problems are discussed frankly and attempted to solve in mutually helpful } \\
\text { way }\end{array}$ & 12 & 11.17574 & 21.026 & $\mathbf{H}_{1}$ \\
\hline 36 & Career development path is shown to the juniors by the seniors & 12 & 14.23426 & 21.026 & $\mathrm{H}_{1}$ \\
\hline 37 & $\begin{array}{l}\text { The growth avenues of the organization are shown to the police personnel } \\
\text { and are helped to prepare for individual development }\end{array}$ & 12 & 12.00609 & 21.026 & $\mathbf{H}_{1}$ \\
\hline 38 & $\begin{array}{l}\text { The police personnel are aware of all the welfare schemes and the welfare } \\
\text { delivery system is smooth and helpful in the police organization }\end{array}$ & 12 & 26.25799 & 21.026 & $\mathbf{H}_{\mathbf{0}}$ \\
\hline 39 & $\begin{array}{l}\text { Job enrichment and job enlargement is practiced in this organization. ('Job } \\
\text { Enrichment' means motivated job performance. 'Job enlargement means ' } \\
\text { enlarging the dimensions of the job.) }\end{array}$ & 12 & 14.025 & 21.026 & $\mathbf{H}_{\mathbf{1}}$ \\
\hline 40 & $\begin{array}{l}\text { The job-rotation helps the development of employees. ('Job rotation' } \\
\text { means changing from one branch to another branch of activities) }\end{array}$ & 12 & 8.535929 & 21.026 & $\mathbf{H}_{1}$ \\
\hline 41 & Employees do not feel suffocated in this organization & 12 & 19.85819 & 21.026 & $\mathbf{H}_{0}$ \\
\hline 42 & $\begin{array}{l}\text { Given an option, the employee will like to rejoin and work in this } \\
\text { organization }\end{array}$ & 12 & 19.37422 & 21.026 & $\mathbf{H}_{0}$ \\
\hline
\end{tabular}


Employees' Association in Police Department With Reference to Khammam District, Telangana State.

\begin{tabular}{|l|l|l|l|l|l|}
\hline 43 & $\begin{array}{l}\text { The police personnel feel that all their interests are taken care of by the } \\
\text { top management }\end{array}$ & 12 & 10.02783 & 21.026 & $\mathbf{H}_{\mathbf{1}}$ \\
\hline 44 & $\begin{array}{l}\text { The police personnel feel that the superiors are not the real hindrance to } \\
\text { their progress }\end{array}$ & 12 & 15.02172 & 21.026 & $\mathbf{H}_{\mathbf{1}}$ \\
\hline 45 & $\begin{array}{l}\text { The police personnel feel that a change of top executive will help to } \\
\text { improve their lot }\end{array}$ & 12 & 8.805564 & 21.026 & $\mathbf{H}_{\mathbf{1}}$ \\
\hline
\end{tabular}

Source: Primary Data

Table 5:- Chi-Square Test based on Age (Police Head Constable)

\begin{tabular}{|c|c|c|c|c|c|}
\hline S.NO & QUESTION.NO & D.F & C.V & T.V & HYPTS \\
\hline 1 & $\begin{array}{l}\text { The top management of Police goes out its way to ensure that the police } \\
\text { personnel enjoy their work }\end{array}$ & 12 & 2.25 & 21.026 & $\mathbf{H}_{1}$ \\
\hline 2 & $\begin{array}{l}\text { The top management believes that people of police system are extremely } \\
\text { important and they should be treated more humanly }\end{array}$ & 12 & 2.85 & 21.026 & $\mathbf{H}_{1}$ \\
\hline 3 & $\begin{array}{l}\text { Developing subordinates is considered as important part of their job by the } \\
\text { top management in Police }\end{array}$ & 12 & 6 & 21.026 & $\mathbf{H}_{1}$ \\
\hline 4 & The personnel policies are helpful to the human development in Police & 12 & 5.025 & 21.026 & $\mathbf{H}_{1}$ \\
\hline 5 & $\begin{array}{l}\text { The top management is willing to invest time and other resources to ensure } \\
\text { the development of the Police personnel }\end{array}$ & 12 & 5.25 & 21.026 & $\mathbf{H}_{1}$ \\
\hline 6 & $\begin{array}{l}\text { The senior officers guide the juniors with interest to help them in their jobs in } \\
\text { Police System }\end{array}$ & 12 & 5.625 & 21.026 & $\mathbf{H}_{1}$ \\
\hline 7 & $\begin{array}{l}\text { The personnel lacking competence are helped to gain competence by the } \\
\text { senior and experienced people }\end{array}$ & 12 & 6 & 21.026 & $\mathbf{H}_{1}$ \\
\hline 8 & $\begin{array}{l}\text { The top executive believes that the behavior of police Personnel can be } \\
\text { changed and can be helped to develop at any stage in their life }\end{array}$ & 12 & 8.4 & 21.026 & $\mathbf{H}_{1}$ \\
\hline 9 & people in Police are helpful to each other & 12 & 3 & 21.026 & $\mathbf{H}_{1}$ \\
\hline 10 & Junior Police people are very informal with their superiors & 12 & 5.625 & 21.026 & $\mathbf{H}_{1}$ \\
\hline 11 & $\begin{array}{l}\text { The junior people in Police discuss their personal problems with the senior } \\
\text { officers and seek guidance for solving them }\end{array}$ & 12 & 6.66 & 21.026 & $\mathbf{H}_{1}$ \\
\hline 12 & $\begin{array}{l}\text { Human relations in Police are so good that any personnel wanting to acquire } \\
\text { new knowledge and skill can do it }\end{array}$ & 12 & 0.75 & 21.026 & $\mathbf{H}_{1}$ \\
\hline 13 & Seniors guide their juniors to prepare for their higher official responsibilities & 12 & 6 & 21.026 & $\mathbf{H}_{1}$ \\
\hline 14 & $\begin{array}{l}\text { The top executive scouts (searches for) for talent in the juniors and identify } \\
\text { that and develop }\end{array}$ & 12 & 3 & 21.026 & $\mathbf{H}_{1}$ \\
\hline 15 & $\begin{array}{l}\text { Promotion in the organization is based on suitability of the person than on } \\
\text { favoritism }\end{array}$ & 12 & 4.285 & 21.026 & $\mathbf{H}_{1}$ \\
\hline 16 & Good work is rewarded in this organization through incentives & 12 & 3.225 & 21.026 & $\mathbf{H}_{1}$ \\
\hline 17 & Good work is always observed and special care is taken to appreciate it & 12 & 5.625 & 21.026 & $\mathbf{H}_{1}$ \\
\hline 18 & $\begin{array}{l}\text { Performance appraisal or confidential reports are based on objective and full } \\
\text { information and not based on favoritism }\end{array}$ & 12 & 3 & 21.026 & $\mathbf{H}_{1}$ \\
\hline 19 & $\begin{array}{l}\text { People in this police system do not have fixed mental impression about each } \\
\text { other }\end{array}$ & 12 & 4.125 & 21.026 & $\mathbf{H}_{1}$ \\
\hline 20 & $\begin{array}{l}\text { The police people are encouraged to experiment with new ideas and try out } \\
\text { creative methods }\end{array}$ & 12 & 3.6 & 21.026 & $\mathbf{H}_{1}$ \\
\hline 21 & $\begin{array}{l}\text { Mistakes made by the police is corrected and not punished by top } \\
\text { management }\end{array}$ & 12 & 3 & 21.026 & $\mathbf{H}_{1}$ \\
\hline 22 & $\begin{array}{l}\text { The mistakes and weaknesses are communicated to the juniors by the seniors } \\
\text { in a polite and non-threatening way }\end{array}$ & 12 & 0.225 & 21.026 & $\mathbf{H}_{1}$ \\
\hline 23 & $\begin{array}{l}\text { The police personnel are given feedback for future correction and } \\
\text { development }\end{array}$ & 12 & 1.5 & 21.026 & $\mathbf{H}_{1}$ \\
\hline 24 & $\begin{array}{l}\text { The personnel in police take efforts to find out their strengths and weaknesses } \\
\text { from their supervising officers and colleagues }\end{array}$ & 12 & 0 & 21.026 & $\mathbf{H}_{1}$ \\
\hline 25 & The training is taken seriously by the Police and they learn from it & 12 & 3 & 21.026 & $\mathbf{H}_{1}$ \\
\hline 26 & The trained personnel are given opportunities to practice their learning & 12 & 3.75 & 21.026 & $\mathbf{H}_{1}$ \\
\hline 27 & Training is imparted based on genuine training needs & 12 & 2.1 & 21.026 & $\mathbf{H}_{1}$ \\
\hline 28 & People trust each other in this organization. & 12 & 2.4 & 21.026 & $\mathbf{H}_{1}$ \\
\hline 29 & $\begin{array}{l}\text { The junior police personnel are not afraid to discuss or express their feelings } \\
\text { with their superiors }\end{array}$ & 12 & 3.75 & 21.026 & $\mathbf{H}_{1}$ \\
\hline 30 & $\begin{array}{l}\text { The personnel do express and discuss their feelings with the subordinates and } \\
\text { peers (colleagues) }\end{array}$ & 12 & 3.75 & 21.026 & $\mathbf{H}_{1}$ \\
\hline 31 & $\begin{array}{l}\text { The police personnel are encouraged to take decisions and initiatives in their } \\
\text { own sphere without waiting for instructions from seniors }\end{array}$ & 12 & 6.375 & 21.026 & $\mathbf{H}_{1}$ \\
\hline 32 & $\begin{array}{l}\text { Delegation of authority to encourage juniors to develop handling higher } \\
\text { responsibilities is quite common in this organization }\end{array}$ & 12 & 3.75 & 21.026 & $\mathbf{H}_{1}$ \\
\hline 33 & $\begin{array}{l}\text { When seniors delegate authority to juniors, the juniors consider it as an } \\
\text { opportunity for development }\end{array}$ & 12 & 5.025 & 21.026 & $\mathbf{H}_{1}$ \\
\hline 34 & Team spirit is very high in this organization & 12 & 6 & 21.026 & $\mathbf{H}_{1}$ \\
\hline 35 & $\begin{array}{l}\text { Problems are discussed frankly and attempted to solve in mutually helpful } \\
\text { way }\end{array}$ & 12 & 3.375 & 21.026 & $\mathbf{H}_{1}$ \\
\hline 36 & Career development path is shown to the juniors by the seniors & 12 & 5.625 & 21.026 & $\mathbf{H}_{1}$ \\
\hline 37 & The growth avenues of the organization are shown to the police personnel and & 12 & 2.25 & 21.026 & $\mathbf{H}_{1}$ \\
\hline
\end{tabular}


Employees' Association in Police Department With Reference to Khammam District, Telangana State.

\begin{tabular}{|l|l|l|l|l|l|}
\hline & are helped to prepare for individual development & & & & \\
\hline 38 & $\begin{array}{l}\text { The police personnel are aware of all the welfare schemes and the welfare } \\
\text { delivery system is smooth and helpful in the police organization }\end{array}$ & 12 & 6.375 & 21.026 & $\mathbf{H}_{\mathbf{1}}$ \\
\hline 39 & $\begin{array}{l}\text { Job enrichment and job enlargement is practiced in this organization. ('Job } \\
\text { Enrichment' means motivated job performance. 'Job enlargement means ' } \\
\text { enlarging the dimensions of the job.) }\end{array}$ & 12 & 3.15 & 21.026 & $\mathbf{H}_{\mathbf{1}}$ \\
\hline 40 & $\begin{array}{l}\text { The job-rotation helps the development of employees. ('Job rotation' means } \\
\text { changing from one branch to another branch of activities) }\end{array}$ & 12 & 0.91 & 21.026 & $\mathbf{H}_{\mathbf{1}}$ \\
\hline 41 & $\begin{array}{l}\text { Employees do not feel suffocated in this organization } \\
\text { Given an option, the employee will like to rejoin and work in this } \\
\text { organization }\end{array}$ & 12 & 6.66 & 21.026 & $\mathbf{H}_{\mathbf{1}}$ \\
\hline 43 & $\begin{array}{l}\text { The police personnel feel that all their interests are taken care of by the top } \\
\text { management }\end{array}$ & 12 & 3.225 & 21.026 & $\mathbf{H}_{\mathbf{1}}$ \\
\hline 44 & $\begin{array}{l}\text { The police personnel feel that the superiors are not the real hindrance to their } \\
\text { progress }\end{array}$ & 12 & 2.625 & 21.026 & $\mathbf{H}_{\mathbf{1}}$ \\
\hline 45 & $\begin{array}{l}\text { The police personnel feel that a change of top executive will help to improve } \\
\text { their lot }\end{array}$ & 12 & 7.5 & 21.026 & $\mathbf{H}_{\mathbf{1}}$ \\
\hline
\end{tabular}

Source: Primary Data

Table 6:- Chi-Square Test based on Age (Sub-Inspector)

\begin{tabular}{|c|c|c|c|c|c|}
\hline S,NO & QUESTION.NO & D.F & C.V & T.V & HYPTS \\
\hline 1 & $\begin{array}{l}\text { The top management of Police goes out its way to ensure that the police } \\
\text { personnel enjoy their work }\end{array}$ & 12 & 6.4 & 21.026 & $\mathbf{H}_{1}$ \\
\hline 2 & $\begin{array}{l}\text { The top management believes that people of police system are extremely } \\
\text { important and they should be treated more humanly }\end{array}$ & 12 & 3.885 & 21.026 & $\mathbf{H}_{1}$ \\
\hline 3 & $\begin{array}{l}\text { Developing subordinates is considered as important part of their job by the } \\
\text { top management in Police }\end{array}$ & 12 & 7.5 & 21.026 & $\mathbf{H}_{1}$ \\
\hline 4 & The personnel policies are helpful to the human development in Police & 12 & 6.4 & 21.026 & $\mathbf{H}_{1}$ \\
\hline 5 & $\begin{array}{l}\text { The top management is willing to invest time and other resources to ensure } \\
\text { the development of the Police personnel }\end{array}$ & 12 & 4.8 & 21.026 & $\mathbf{H}_{1}$ \\
\hline 6 & $\begin{array}{l}\text { The senior officers guide the juniors with interest to help them in their jobs } \\
\text { in Police System }\end{array}$ & 12 & 1.714 & 21.026 & $\mathbf{H}_{1}$ \\
\hline 7 & $\begin{array}{l}\text { The personnel lacking competence are helped to gain competence by the } \\
\text { senior and experienced people }\end{array}$ & 12 & 4.2 & 21.026 & $\mathbf{H}_{1}$ \\
\hline 8 & $\begin{array}{l}\text { The top executive believes } \mathrm{t} h \text { a } \mathrm{t} \text { the behavior of police Personnel can be } \\
\text { changed and can be helped to develop a t any stage in their life }\end{array}$ & 12 & 3.65 & 21.026 & $\mathbf{H}_{1}$ \\
\hline 9 & people in Police are helpful to each other & 12 & 2.4 & 21.026 & $\mathbf{H}_{1}$ \\
\hline 10 & Junior Police people are very informal with their superiors & 12 & 4.64 & 21.026 & $\mathbf{H}_{1}$ \\
\hline 11 & $\begin{array}{l}\text { The junior people in Police discuss their personal problems with the senior } \\
\text { officers and seek guidance for solving them }\end{array}$ & 12 & 3.885 & 21.026 & $\mathbf{H}_{1}$ \\
\hline 12 & $\begin{array}{l}\text { Human relations in Police are so good that any personnel wanting to acquire } \\
\text { new knowledge and skill can do it }\end{array}$ & 12 & 14.8 & 21.026 & $\mathbf{H}_{1}$ \\
\hline 13 & Seniors guide their juniors to prepare for their higher official responsibilities & 12 & 15.2 & 21.026 & $\mathbf{H}_{1}$ \\
\hline 14 & $\begin{array}{l}\text { The top executive scouts (searches for) for talent in the juniors and identify } \\
\text { that and develop }\end{array}$ & 12 & 7.5 & 21.026 & $\mathbf{H}_{1}$ \\
\hline 15 & $\begin{array}{l}\text { Promotion in the organization is based on suitability of the person than on } \\
\text { favoritism }\end{array}$ & 12 & 4.2 & 21.026 & $\mathbf{H}_{1}$ \\
\hline 16 & Good work is rewarded in this organization through incentives & 12 & 3.36 & 21.026 & $\mathbf{H}_{1}$ \\
\hline 17 & Good work is always observed and special care is taken to appreciate it & 12 & 6.4 & 21.026 & $\mathbf{H}_{1}$ \\
\hline 18 & $\begin{array}{l}\text { Performance appraisal or confidential reports are based on objective and full } \\
\text { information and not based on favoritism }\end{array}$ & 12 & 13 & 21.026 & $\mathbf{H}_{1}$ \\
\hline 19 & $\begin{array}{l}\text { People in this police system do not have fixed mental impression about each } \\
\text { other }\end{array}$ & 12 & 8.6 & 21.026 & $\mathbf{H}_{1}$ \\
\hline 20 & $\begin{array}{l}\text { The police people are encouraged to experiment with new ideas and try out } \\
\text { creative methods }\end{array}$ & 12 & 3.36 & 21.026 & $\mathbf{H}_{1}$ \\
\hline 21 & $\begin{array}{l}\text { Mistakes made by the police is corrected and not punished by top } \\
\text { management }\end{array}$ & 12 & 7.2 & 21.026 & $\mathbf{H}_{1}$ \\
\hline 22 & $\begin{array}{l}\text { The mistakes and weaknesses are communicated to the juniors by the } \\
\text { seniors in a polite and non-threatening way }\end{array}$ & 12 & 13 & 21.026 & $\mathbf{H}_{1}$ \\
\hline 23 & $\begin{array}{l}\text { The police personnel are given feedback for future correction and } \\
\text { development }\end{array}$ & 12 & 3.885 & 21.026 & $\mathbf{H}_{1}$ \\
\hline 24 & $\begin{array}{l}\text { The personnel in police take efforts to find out their strengths and } \\
\text { weaknesses from their supervising officers and colleagues }\end{array}$ & 12 & 14.1 & 21.026 & $\mathbf{H}_{1}$ \\
\hline 25 & The training is taken seriously by the Police and they learn from it & 12 & 2.4 & 21.026 & $\mathbf{H}_{1}$ \\
\hline 26 & The trained personnel are given opportunities to practice their learning & 12 & 2.4 & 21.026 & $\mathbf{H}_{1}$ \\
\hline 27 & Training is imparted based on genuine training needs & 12 & 1.2 & 21.026 & $\mathbf{H}_{1}$ \\
\hline 28 & People trust each other in this organization. & 12 & 3.36 & 21.026 & $\mathbf{H}_{1}$ \\
\hline 29 & $\begin{array}{l}\text { The junior police personnel are not afraid to discuss or express their feelings } \\
\text { with their superiors }\end{array}$ & 12 & 10.8 & 21.026 & $\mathbf{H}_{1}$ \\
\hline 30 & $\begin{array}{l}\text { The personnel do express and discuss their feelings with the subordinates } \\
\text { and peers (colleagues) }\end{array}$ & 12 & 6.84 & 21.026 & $\mathbf{H}_{1}$ \\
\hline
\end{tabular}




\begin{tabular}{|c|c|c|c|c|c|}
\hline 31 & $\begin{array}{l}\text { The police personnel are encouraged to take decisions and initiatives in their } \\
\text { own sphere without waiting for instructions from seniors }\end{array}$ & 12 & 4.8 & 21.026 & $\mathbf{H}_{1}$ \\
\hline 32 & $\begin{array}{l}\text { Delegation of authority to encourage juniors to develop handling higher } \\
\text { responsibilities is quite common in this organization }\end{array}$ & 12 & 5.3 & 21.026 & $\mathrm{H}_{1}$ \\
\hline 33 & $\begin{array}{l}\text { When seniors delegate authority to juniors, the juniors consider it as an } \\
\text { opportunity for development }\end{array}$ & 12 & 3.1 & 21.026 & $\mathbf{H}_{1}$ \\
\hline 34 & Team spirit is very high in this organization & 12 & 7.5 & 21.026 & $\mathbf{H}_{1}$ \\
\hline 35 & $\begin{array}{l}\text { Problems are discussed frankly and attempted to solve in mutually helpful } \\
\text { way }\end{array}$ & 12 & 6.4 & 21.026 & $\mathrm{H}_{1}$ \\
\hline 36 & Career development path is shown to the juniors by the seniors & 12 & 6.085 & 21.026 & $\mathbf{H}_{1}$ \\
\hline 37 & $\begin{array}{l}\text { The growth avenues of the organization are shown to the police personnel } \\
\text { and are helped to prepare for individual development }\end{array}$ & 12 & 12 & 21.026 & $\mathbf{H}_{1}$ \\
\hline 38 & $\begin{array}{l}\text { The police personnel are aware of all the welfare schemes and the welfare } \\
\text { delivery system is smooth and helpful in the police organization }\end{array}$ & 12 & 4.2 & 21.026 & $\mathbf{H}_{1}$ \\
\hline 39 & $\begin{array}{l}\text { Job enrichment and job enlargement is practiced in this organization. ('Job } \\
\text { Enrichment' means motivated job performance. 'Job enlargement means ' } \\
\text { enlarging the dimensions of the job.) }\end{array}$ & 12 & 8.6 & 21.026 & $\mathbf{H}_{1}$ \\
\hline 40 & $\begin{array}{l}\text { The job-rotation helps the development of employees. ('Job rotation' means } \\
\text { changing from one branch to another branch of activities) }\end{array}$ & 12 & 5.3 & 21.026 & $\mathrm{H}_{1}$ \\
\hline 41 & Employees do not feel suffocated in this organization & 12 & 4.714 & 21.026 & $\mathbf{H}_{1}$ \\
\hline 42 & $\begin{array}{l}\text { Given an option, the employee will like to rejoin and work in this } \\
\text { organization }\end{array}$ & 12 & 8.6 & 21.026 & $\mathrm{H}_{1}$ \\
\hline 43 & $\begin{array}{l}\text { The police personnel feel that all their interests are taken care of by the top } \\
\text { management }\end{array}$ & 12 & 6.84 & 21.026 & $\mathrm{H}_{1}$ \\
\hline 44 & $\begin{array}{l}\text { The police personnel feel that the superiors are not the real hindrance to } \\
\text { their progress }\end{array}$ & 12 & 3.1 & 21.026 & $\mathrm{H}_{1}$ \\
\hline 45 & $\begin{array}{l}\text { The police personnel feel that a change of top executive will help to } \\
\text { improve their lot }\end{array}$ & 12 & 14.1 & 21.026 & $\mathbf{H}_{1}$ \\
\hline
\end{tabular}

Source: Primary Data

Table 7:- Chi-Square Test based on Age (Circular Inspector)

\begin{tabular}{|c|c|c|c|c|c|}
\hline S.NO & QUESTION.NO & D.F & C.V & T.V & HYPTS \\
\hline 1 & $\begin{array}{l}\text { The top management of Police goes out its way to ensure that the } \\
\text { police personnel enjoy their work }\end{array}$ & 12 & 2.222222 & 21.026 & $\mathbf{H}_{1}$ \\
\hline 2 & $\begin{array}{l}\text { The top management believes that people of police system are } \\
\text { extremely important and they should be treated more humanly }\end{array}$ & 12 & 5 & 21.026 & $\mathbf{H}_{1}$ \\
\hline 3 & $\begin{array}{l}\text { Developing subordinates is considered as important part of their job by } \\
\text { the top management in Police }\end{array}$ & 12 & 2.222222 & 21.026 & $\mathbf{H}_{1}$ \\
\hline 4 & The personnel policies are helpful to the human development in Police & 12 & 3.333333 & 21.026 & $\mathbf{H}_{1}$ \\
\hline 5 & $\begin{array}{l}\text { The top management is willing to invest time and other resources to } \\
\text { ensure the development of the Police personnel }\end{array}$ & 12 & 3.333333 & 21.026 & $\mathrm{H}_{1}$ \\
\hline 6 & $\begin{array}{l}\text { The senior officers guide the juniors with interest to help them in their } \\
\text { jobs in Police System }\end{array}$ & 12 & 2.222222 & 21.026 & $\mathbf{H}_{1}$ \\
\hline 7 & $\begin{array}{l}\text { The personnel lacking competence are helped to gain competence by } \\
\text { the senior and experienced people }\end{array}$ & 12 & 3.333333 & 21.026 & $\mathbf{H}_{1}$ \\
\hline 8 & $\begin{array}{l}\text { The top executive believes } \mathrm{t} h \text { a } \mathrm{t} \text { the behavior of police Personnel can } \\
\text { be changed and can be helped to develop a t any stage in their life }\end{array}$ & 12 & 3.333333 & 21.026 & $\mathbf{H}_{1}$ \\
\hline 9 & people in Police are helpful to each other & 12 & 3.333333 & 21.026 & $\mathbf{H}_{1}$ \\
\hline 10 & Junior Police people are very informal with their superiors & 12 & 6.666667 & 21.026 & $\mathbf{H}_{1}$ \\
\hline 11 & $\begin{array}{l}\text { The junior people in Police discuss their personal problems with the } \\
\text { senior officers and seek guidance for solving them }\end{array}$ & 12 & 6.666667 & 21.026 & $\mathbf{H}_{1}$ \\
\hline 12 & $\begin{array}{l}\text { Human relations in Police are so good that any personnel wanting to } \\
\text { acquire new knowledge and skill can do it }\end{array}$ & 12 & 10 & 21.026 & $\mathbf{H}_{1}$ \\
\hline 13 & $\begin{array}{l}\text { Seniors guide their juniors to prepare for their higher official } \\
\text { responsibilities }\end{array}$ & 12 & 2.222222 & 21.026 & $\mathbf{H}_{1}$ \\
\hline 14 & $\begin{array}{l}\text { The top executive scouts (searches for) for talent in the juniors and } \\
\text { identify that and develop }\end{array}$ & 12 & 6.666667 & 21.026 & $\mathbf{H}_{1}$ \\
\hline 15 & $\begin{array}{l}\text { Promotion in the organization is based on suitability of the person than } \\
\text { on favoritism }\end{array}$ & 12 & 6.666667 & 21.026 & $\mathbf{H}_{1}$ \\
\hline 16 & Good work is rewarded in this organization through incentives & 12 & 3.333333 & 21.026 & $\mathbf{H}_{1}$ \\
\hline 17 & Good work is always observed and special care is taken to appreciate it & 12 & 6.666667 & 21.026 & $\mathbf{H}_{1}$ \\
\hline 18 & $\begin{array}{l}\text { Performance appraisal or confidential reports are based on objective } \\
\text { and full information and not based on favoritism }\end{array}$ & 12 & 6.666667 & 21.026 & $\mathbf{H}_{1}$ \\
\hline 19 & $\begin{array}{l}\text { People in this police system do not have fixed mental impression about } \\
\text { each other }\end{array}$ & 12 & 6.666667 & 21.026 & $\mathbf{H}_{1}$ \\
\hline 20 & $\begin{array}{l}\text { The police people are encouraged to experiment with new ideas and try } \\
\text { out creative methods }\end{array}$ & 12 & 6.666667 & 21.026 & $\mathbf{H}_{1}$ \\
\hline 21 & $\begin{array}{l}\text { Mistakes made by the police is corrected and not punished by top } \\
\text { management }\end{array}$ & 12 & 6.666667 & 21.026 & $\mathbf{H}_{1}$ \\
\hline 22 & $\begin{array}{l}\text { The mistakes and weaknesses are communicated to the juniors by the } \\
\text { seniors in a polite and non-threatening way }\end{array}$ & 12 & 6.666667 & 21.026 & $\mathbf{H}_{1}$ \\
\hline
\end{tabular}




\begin{tabular}{|c|c|c|c|c|c|}
\hline 23 & $\begin{array}{l}\text { The police personnel are given feedback for future correction and } \\
\text { development }\end{array}$ & 12 & 3.333333 & 21.026 & $\overline{\mathbf{H}_{1}}$ \\
\hline 24 & $\begin{array}{l}\text { The personnel in police take efforts to find out their strengths and } \\
\text { weaknesses from their supervising officers and colleagues }\end{array}$ & 12 & 6.666667 & 21.026 & $\mathbf{H}_{1}$ \\
\hline 25 & The training is taken seriously by the Police and they learn from it & 12 & 6.666667 & 21.026 & $\mathbf{H}_{1}$ \\
\hline 26 & The trained personnel are given opportunities to practice their learning & 12 & 3.333333 & 21.026 & $\mathbf{H}_{1}$ \\
\hline 27 & Training is imparted based on genuine training needs & 12 & 6.666667 & 21.026 & $\mathbf{H}_{1}$ \\
\hline 28 & People trust each other in this organization. & 12 & 3.333333 & 21.026 & $\mathbf{H}_{1}$ \\
\hline 29 & $\begin{array}{l}\text { The junior police personnel are not afraid to discuss or express their } \\
\text { feelings with their superiors }\end{array}$ & 12 & 3.333333 & 21.026 & $\mathbf{H}_{1}$ \\
\hline 30 & $\begin{array}{l}\text { The personnel do express and discuss their feelings with the } \\
\text { subordinates and peers (colleagues) }\end{array}$ & 12 & 3.333333 & 21.026 & $\mathbf{H}_{1}$ \\
\hline 31 & $\begin{array}{l}\text { The police personnel are encouraged to take decisions and initiatives in } \\
\text { their own sphere without waiting for instructions from seniors }\end{array}$ & 12 & 2.222222 & 21.026 & $\mathbf{H}_{1}$ \\
\hline 32 & $\begin{array}{l}\text { Delegation of authority to encourage juniors to develop handling } \\
\text { higher responsibilities is quite common in this organization }\end{array}$ & 12 & 3.333333 & 21.026 & $\mathbf{H}_{1}$ \\
\hline 33 & $\begin{array}{l}\text { When seniors delegate authority to juniors, the juniors consider it as an } \\
\text { opportunity for development }\end{array}$ & 12 & 3.333333 & 21.026 & $\overline{\mathbf{H}_{1}}$ \\
\hline 34 & Team spirit is very high in this organization & 12 & 6.666667 & 21.026 & $\mathbf{H}_{1}$ \\
\hline 35 & $\begin{array}{l}\text { Problems are discussed frankly and attempted to solve in mutually } \\
\text { helpful way }\end{array}$ & 12 & 10 & 21.026 & $\mathbf{H}_{1}$ \\
\hline 36 & Career development path is shown to the juniors by the seniors & 12 & 6.666667 & 21.026 & $\mathbf{H}_{1}$ \\
\hline 37 & $\begin{array}{l}\text { The growth avenues of the organization are shown to the police } \\
\text { personnel and are helped to prepare for individual development }\end{array}$ & 12 & 6.666667 & 21.026 & $\mathbf{H}_{1}$ \\
\hline 38 & $\begin{array}{l}\text { The police personnel are aware of all the welfare schemes and the } \\
\text { welfare delivery system is smooth and helpful in the police } \\
\text { organization }\end{array}$ & 12 & 6.666667 & 21.026 & $\mathbf{H}_{1}$ \\
\hline 39 & $\begin{array}{l}\text { Job enrichment and job enlargement is practiced in this organization. } \\
\text { ('Job Enrichment' means motivated job performance. 'Job enlargement } \\
\text { means ' enlarging the dimensions of the job.) }\end{array}$ & 12 & 10 & 21.026 & $\mathbf{H}_{1}$ \\
\hline 40 & $\begin{array}{l}\text { The job-rotation helps the development of employees. ('Job rotation' } \\
\text { means changing from one branch to another branch of activities) }\end{array}$ & 12 & 5 & 21.026 & $\mathbf{H}_{1}$ \\
\hline 41 & Employees do not feel suffocated in this organization & 12 & 5 & 21.026 & $\mathbf{H}_{1}$ \\
\hline 42 & $\begin{array}{l}\text { Given an option, the employee will like to rejoin and work in this } \\
\text { organization }\end{array}$ & 12 & 6.666667 & 21.026 & $\mathbf{H}_{1}$ \\
\hline 43 & $\begin{array}{l}\text { The police personnel feel that all their interests are taken care of by the } \\
\text { top management }\end{array}$ & 12 & 2.222222 & 21.026 & $\mathbf{H}_{1}$ \\
\hline 44 & $\begin{array}{l}\text { The police personnel feel that the superiors are not the real hindrance } \\
\text { to their progress }\end{array}$ & 12 & 3.333333 & 21.026 & $\mathbf{H}_{1}$ \\
\hline 45 & $\begin{array}{l}\text { The police personnel feel that a change of top executive will help to } \\
\text { improve their lot }\end{array}$ & 12 & 2.222222 & 21.026 & $\mathbf{H}_{1}$ \\
\hline
\end{tabular}

Source: Primary Data

Table 8:- Chi-Square Test based on Age (Women Police Constable)

\begin{tabular}{|c|c|c|c|c|c|}
\hline S.NO & QUESTION.NO & D.F & C.V & T.V & HYPTS \\
\hline 1 & $\begin{array}{l}\text { The top management of Police goes out its way to ensure that the police } \\
\text { personnel enjoy their work }\end{array}$ & 12 & 5 & 21.026 & $\mathbf{H}_{\mathbf{1}}$ \\
\hline 2 & $\begin{array}{l}\text { The top management believes that people of police system are extremely } \\
\text { important and they should be treated more humanly }\end{array}$ & 12 & 1.875 & 21.026 & $\mathbf{H}_{1}$ \\
\hline 3 & $\begin{array}{l}\text { Developing subordinates is considered as important part of their job by } \\
\text { the top management in Police }\end{array}$ & 12 & 5 & 21.026 & $\mathbf{H}_{1}$ \\
\hline 4 & The personnel policies are helpful to the human development in Police & 12 & 5 & 21.026 & $\mathbf{H}_{1}$ \\
\hline 5 & $\begin{array}{l}\text { The top management is willing to invest time and other resources to } \\
\text { ensure the development of the Police personnel }\end{array}$ & 12 & 0.833 & 21.026 & $\mathbf{H}_{1}$ \\
\hline 6 & $\begin{array}{l}\text { The senior officers guide the juniors with interest to help them in their } \\
\text { jobs in Police System }\end{array}$ & 12 & 0.833 & 21.026 & $\mathbf{H}_{1}$ \\
\hline 7 & $\begin{array}{l}\text { The personnel lacking competence are helped to gain competence by the } \\
\text { senior and experienced people }\end{array}$ & 12 & 5 & 21.026 & $\mathbf{H}_{1}$ \\
\hline 8 & $\begin{array}{l}\text { The top executive believes } t \mathrm{~h} \text { a } \mathrm{t} \text { the behavior of police Personnel can be } \\
\text { changed and can be helped to develop a } \mathrm{t} \text { any stage in their life }\end{array}$ & 12 & 1.875 & 21.026 & $\mathbf{H}_{1}$ \\
\hline 9 & people in Police are helpful to each other & 12 & 5 & 21.026 & $\mathbf{H}_{1}$ \\
\hline 10 & Junior Police people are very informal with their superiors & 12 & 5 & 21.026 & $\mathbf{H}_{1}$ \\
\hline 11 & $\begin{array}{l}\text { The junior people in Police discuss their personal problems with the } \\
\text { senior officers and seek guidance for solving them }\end{array}$ & 12 & 5 & 21.026 & $\mathbf{H}_{1}$ \\
\hline 12 & $\begin{array}{l}\text { Human relations in Police are so good that any personnel wanting to } \\
\text { acquire new knowledge and skill can do it }\end{array}$ & 12 & 5 & 21.026 & $\mathbf{H}_{1}$ \\
\hline 13 & $\begin{array}{l}\begin{array}{l}\text { Seniors guide their juniors to prepare for their higher official } \\
\text { responsibilities }\end{array} \\
\end{array}$ & 12 & 1.875 & 21.026 & $\mathbf{H}_{1}$ \\
\hline 14 & $\begin{array}{l}\text { The top executive scouts (searches for) for talent in the juniors and } \\
\text { identify that and develop }\end{array}$ & 12 & 0.833 & 21.026 & $\mathbf{H}_{1}$ \\
\hline 15 & Promotion in the organization is based on suitability of the person than & 12 & 1.875 & 21.026 & $\mathbf{H}_{1}$ \\
\hline
\end{tabular}




\begin{tabular}{|c|c|c|c|c|c|}
\hline & on favoritism & & & & \\
\hline 16 & Good work is rewarded in this organization through incentives & 12 & 5 & 21.026 & $\mathbf{H}_{1}$ \\
\hline 17 & Good work is always observed and special care is taken to appreciate it & 12 & 1.875 & 21.026 & $\mathrm{H}_{1}$ \\
\hline 18 & $\begin{array}{l}\text { Performance appraisal or confidential reports are based on objective and } \\
\text { full information and not based on favoritism }\end{array}$ & 12 & 1.833 & 21.026 & $\mathbf{H}_{1}$ \\
\hline 19 & $\begin{array}{l}\text { People in this police system do not have fixed mental impression about } \\
\text { each other }\end{array}$ & 12 & 1.875 & 21.026 & $\mathbf{H}_{\mathbf{1}}$ \\
\hline 20 & $\begin{array}{l}\text { The police people are encouraged to experiment with new ideas and try } \\
\text { out creative methods }\end{array}$ & 12 & 5 & 21.026 & $\mathbf{H}_{1}$ \\
\hline 21 & $\begin{array}{l}\text { Mistakes made by the police is corrected and not punished by top } \\
\text { management }\end{array}$ & 12 & 5 & 21.026 & $\mathbf{H}_{1}$ \\
\hline 22 & $\begin{array}{l}\text { The mistakes and weaknesses are communicated to the juniors by the } \\
\text { seniors in a polite and non-threatening way }\end{array}$ & 12 & 0.833 & 21.026 & $\mathbf{H}_{1}$ \\
\hline 23 & $\begin{array}{l}\text { The police personnel are given feedback for future correction and } \\
\text { development }\end{array}$ & 12 & 5 & 21.026 & $\mathbf{H}_{1}$ \\
\hline 24 & $\begin{array}{l}\text { The personnel in police take efforts to find out their strengths and } \\
\text { weaknesses from their supervising officers and colleagues }\end{array}$ & 12 & 5 & 21.026 & $\mathbf{H}_{1}$ \\
\hline 25 & The training is taken seriously by the Police and they learn from it & 12 & 5 & 21.026 & $\mathbf{H}_{1}$ \\
\hline 26 & The trained personnel are given opportunities to practice their learning & 12 & 1.875 & 21.026 & $\mathbf{H}_{1}$ \\
\hline 27 & Training is imparted based on genuine training needs & 12 & 5 & 21.026 & $\mathbf{H}_{1}$ \\
\hline 28 & People trust each other in this organization. & 12 & 0.833 & 21.026 & $\mathbf{H}_{1}$ \\
\hline 29 & $\begin{array}{l}\text { The junior police personnel are not afraid to discuss or express their } \\
\text { feelings with their superiors }\end{array}$ & 12 & 0.833 & 21.026 & $\overline{\mathbf{H}_{1}}$ \\
\hline 30 & $\begin{array}{l}\text { The personnel do express and discuss their feelings with the subordinates } \\
\text { and peers (colleagues) }\end{array}$ & 12 & 0.833 & 21.026 & $\mathbf{H}_{1}$ \\
\hline 31 & $\begin{array}{l}\text { The police personnel are encouraged to take decisions and initiatives in } \\
\text { their own sphere without waiting for instructions from seniors }\end{array}$ & 12 & 0.833 & 21.026 & $\mathbf{H}_{1}$ \\
\hline 32 & $\begin{array}{l}\text { Delegation of authority to encourage juniors to develop handling higher } \\
\text { responsibilities is quite common in this organization }\end{array}$ & 12 & 1.875 & 21.026 & $\mathbf{H}_{1}$ \\
\hline 33 & $\begin{array}{l}\text { When seniors delegate authority to juniors, the juniors consider it as an } \\
\text { opportunity for development }\end{array}$ & 12 & 5 & 21.026 & $\overline{\mathbf{H}_{1}}$ \\
\hline 34 & Team spirit is very high in this organization & 12 & 1.875 & 21.026 & $\mathbf{H}_{1}$ \\
\hline 35 & $\begin{array}{l}\text { Problems are discussed frankly and attempted to solve in mutually } \\
\text { helpful way }\end{array}$ & 12 & 1.875 & 21.026 & $\overline{\mathbf{H}_{1}}$ \\
\hline 36 & Career development path is shown to the juniors by the seniors & 12 & 5 & 21.026 & $\mathbf{H}_{1}$ \\
\hline 37 & $\begin{array}{l}\text { The growth avenues of the organization are shown to the police personnel } \\
\text { and are helped to prepare for individual development }\end{array}$ & 12 & 5 & 21.026 & $\overline{\mathbf{H}_{1}}$ \\
\hline 38 & $\begin{array}{l}\text { The police personnel are aware of all the welfare schemes and the } \\
\text { welfare delivery system is smooth and helpful in the police organization }\end{array}$ & 12 & 5 & 21.026 & $\mathbf{H}_{1}$ \\
\hline 39 & $\begin{array}{l}\text { Job enrichment and job enlargement is practiced in this organization. } \\
\text { ('Job Enrichment' means motivated job performance. 'Job enlargement } \\
\text { means ' enlarging the dimensions of the job.) }\end{array}$ & 12 & 0.833 & 21.026 & $\mathbf{H}_{1}$ \\
\hline 40 & $\begin{array}{l}\text { The job-rotation helps the development of employees. ('Job rotation' } \\
\text { means changing from one branch to another branch of activities) }\end{array}$ & 12 & 1.875 & 21.026 & $\mathbf{H}_{1}$ \\
\hline 41 & Employees do not feel suffocated in this organization & 12 & 1.875 & 21.026 & $\mathbf{H}_{1}$ \\
\hline 42 & $\begin{array}{l}\text { Given an option, the employee will like to rejoin and work in this } \\
\text { organization }\end{array}$ & 12 & 0.833 & 21.026 & $\overline{\mathbf{H}_{1}}$ \\
\hline 43 & $\begin{array}{l}\text { The police personnel feel that all their interests are taken care of by the } \\
\text { top management }\end{array}$ & 12 & 1.875 & 21.026 & $\mathbf{H}_{1}$ \\
\hline 44 & $\begin{array}{l}\text { The police personnel feel that the superiors are not the real hindrance to } \\
\text { their progress }\end{array}$ & 12 & 0.833 & 21.026 & $\mathbf{H}_{1}$ \\
\hline 45 & $\begin{array}{l}\text { The police personnel feel that a change of top executive will help to } \\
\text { improve their lot }\end{array}$ & 12 & 5 & 21.026 & $\overline{\mathbf{H}_{1}}$ \\
\hline
\end{tabular}

Source: Primary Data

Table 9:- Chi-Square Test based on Age (Women Head Constable)

\begin{tabular}{|l|l|l|l|l|l|}
\hline S.NO & QUESTION.NO & $\mathbf{D . F}$ & $\mathbf{C . V}$ & $\mathbf{T . V}$ & $\mathbf{H Y P T S}$ \\
\hline 1 & $\begin{array}{l}\text { The top management of Police goes out its way to ensure that the } \\
\text { police personnel enjoy their work }\end{array}$ & 12 & 0.833 & 21.026 & $\mathbf{H}_{\mathbf{1}}$ \\
\hline 2 & $\begin{array}{l}\text { The top management believes that people of police system are } \\
\text { extremely important and they should be treated more humanly }\end{array}$ & 12 & 2.916 & 21.026 & $\mathbf{H}_{\mathbf{1}}$ \\
\hline 3 & $\begin{array}{l}\text { Developing subordinates is considered as important part of their job by } \\
\text { the top management in Police }\end{array}$ & 12 & 2.916 & 21.026 & $\mathbf{H}_{\mathbf{1}}$ \\
\hline 4 & $\begin{array}{l}\text { The personnel policies are helpful to the human development in Police } \\
\text { The top management is willing to invest time and other resources to } \\
\text { ensure the development of the Police personnel }\end{array}$ & 12 & 2.916 & 21.026 & $\mathbf{H}_{\mathbf{1}}$ \\
\hline 5 & $\begin{array}{l}\text { The senior officers guide the juniors with interest to help them in their } \\
\text { jobs in Police System }\end{array}$ & 12 & 2.222 & 21.026 & $\mathbf{H}_{\mathbf{1}}$ \\
\hline 6 & $\begin{array}{l}\text { The personnel lacking competence are helped to gain competence by } \\
\text { the senior and experienced people }\end{array}$ & 12 & 2.222 & 21.026 & $\mathbf{H}_{\mathbf{1}}$ \\
\hline
\end{tabular}




\begin{tabular}{|c|c|c|c|c|c|}
\hline 8 & $\begin{array}{l}\text { The top executive believes } \mathrm{t} h \text { a } \mathrm{t} \text { the behavior of police Personnel can } \\
\text { be changed and can be helped to develop a t any stage in their life }\end{array}$ & 12 & 2.222 & 21.026 & $\mathbf{H}_{1}$ \\
\hline 9 & people in Police are helpful to each other & 12 & 2.916 & 21.026 & $\mathbf{H}_{1}$ \\
\hline 10 & Junior Police people are very informal with their superiors & 12 & 5 & 21.026 & $\mathbf{H}_{1}$ \\
\hline 11 & $\begin{array}{l}\text { The junior people in Police discuss their personal problems with the } \\
\text { senior officers and seek guidance for solving them }\end{array}$ & 12 & 2.916 & 21.026 & $\mathbf{H}_{1}$ \\
\hline 12 & $\begin{array}{l}\text { Human relations in Police are so good that any personnel wanting to } \\
\text { acquire new knowledge and skill can do it }\end{array}$ & 12 & 2.222 & 21.026 & $\mathbf{H}_{1}$ \\
\hline 13 & $\begin{array}{l}\text { Seniors guide their juniors to prepare for their higher official } \\
\text { responsibilities }\end{array}$ & 12 & 2.916 & 21.026 & $\mathbf{H}_{1}$ \\
\hline 14 & $\begin{array}{l}\text { The top executive scouts (searches for) for talent in the juniors and } \\
\text { identify that and develop }\end{array}$ & 12 & 2.916 & 21.026 & $\mathrm{H}_{1}$ \\
\hline 15 & $\begin{array}{l}\text { Promotion in the organization is based on suitability of the person than } \\
\text { on favoritism. }\end{array}$ & 12 & 2.916 & 21.026 & $\mathbf{H}_{1}$ \\
\hline 16 & Good work is rewarded in this organization through incentives & 12 & 2.916 & 21.026 & $\mathbf{H}_{1}$ \\
\hline 17 & $\begin{array}{l}\text { Good work is always observed and special care is taken to appreciate } \\
\text { it }\end{array}$ & 12 & 0.138 & 21.026 & $\mathbf{H}_{1}$ \\
\hline 18 & $\begin{array}{l}\text { Performance appraisal or confidential reports are based on objective } \\
\text { and full information and not based on favoritism }\end{array}$ & 12 & 0.833 & 21.026 & $\mathbf{H}_{1}$ \\
\hline 19 & $\begin{array}{l}\text { People in this police system do not have fixed mental impression about } \\
\text { each other }\end{array}$ & 12 & 2.916 & 21.026 & $\mathbf{H}_{1}$ \\
\hline 20 & $\begin{array}{l}\text { The police people are encouraged to experiment with new ideas and } \\
\text { try out creative methods }\end{array}$ & 12 & 2.916 & 21.026 & $\mathbf{H}_{1}$ \\
\hline 21 & $\begin{array}{l}\text { Mistakes made by the police is corrected and not punished by top } \\
\text { management }\end{array}$ & 12 & 0.138 & 21.026 & $\mathrm{H}_{1}$ \\
\hline 22 & $\begin{array}{l}\text { The mistakes and weaknesses are communicated to the juniors by the } \\
\text { seniors in a polite and non-threatening way }\end{array}$ & 12 & 2.222 & 21.026 & $\mathbf{H}_{1}$ \\
\hline 23 & $\begin{array}{l}\text { The police personnel are given feedback for future correction and } \\
\text { development }\end{array}$ & 12 & 2.916 & 21.026 & $\mathrm{H}_{1}$ \\
\hline 24 & $\begin{array}{l}\text { The personnel in police take efforts to find out their strengths and } \\
\text { weaknesses from their supervising officers and colleagues }\end{array}$ & 12 & 2.916 & 21.026 & $\mathbf{H}_{1}$ \\
\hline 25 & The training is taken seriously by the Police and they learn from it & 12 & 2.22 & 21.026 & $\mathbf{H}_{1}$ \\
\hline 26 & The trained personnel are given opportunities to practice their learning & 12 & 5 & 21.026 & $\mathbf{H}_{1}$ \\
\hline 27 & Training is imparted based on genuine training needs & 12 & 5 & 21.026 & $\mathbf{H}_{1}$ \\
\hline 28 & People trust each other in this organization. & 12 & 0.833 & 21.026 & $\mathbf{H}_{1}$ \\
\hline 29 & $\begin{array}{l}\text { The junior police personnel are not afraid to discuss or express their } \\
\text { feelings with their superiors }\end{array}$ & 12 & 0.833 & 21.026 & $\mathbf{H}_{\mathbf{1}}$ \\
\hline 30 & $\begin{array}{l}\text { The personnel do express and discuss their feelings with the } \\
\text { subordinates and peers (colleagues) }\end{array}$ & 12 & 5 & 21.026 & $\mathbf{H}_{\mathbf{1}}$ \\
\hline 31 & $\begin{array}{l}\text { The police personnel are encouraged to take decisions and initiatives } \\
\text { in their own sphere without waiting for instructions from seniors }\end{array}$ & 12 & 2.222 & 21.026 & $\mathbf{H}_{\mathbf{1}}$ \\
\hline 32 & $\begin{array}{l}\text { Delegation of authority to encourage juniors to develop handling } \\
\text { higher responsibilities is quite common in this organization }\end{array}$ & 12 & 0.833 & 21.026 & $\mathbf{H}_{1}$ \\
\hline 33 & $\begin{array}{l}\text { When seniors delegate authority to juniors, the juniors consider it as an } \\
\text { opportunity for development }\end{array}$ & 12 & 2.916 & 21.026 & $\mathbf{H}_{1}$ \\
\hline 34 & Team spirit is very high in this organization & 12 & 5 & 21.026 & $\mathbf{H}_{1}$ \\
\hline 35 & $\begin{array}{l}\text { Problems are discussed frankly and attempted to solve in mutually } \\
\text { helpful way }\end{array}$ & 12 & 2.222 & 21.026 & $\mathbf{H}_{1}$ \\
\hline 36 & Career development path is shown to the juniors by the seniors & 12 & 2.222 & 21.026 & $\mathbf{H}_{1}$ \\
\hline 37 & $\begin{array}{l}\text { The growth avenues of the organization are shown to the police } \\
\text { personnel and are helped to prepare for individual development }\end{array}$ & 12 & 2.916 & 21.026 & $\mathbf{H}_{\mathbf{1}}$ \\
\hline 38 & $\begin{array}{l}\text { The police personnel are aware of all the welfare schemes and the } \\
\text { welfare delivery system is smooth and helpful in the police } \\
\text { organization }\end{array}$ & 12 & 2.916 & 21.026 & $\mathbf{H}_{1}$ \\
\hline 39 & $\begin{array}{l}\text { Job enrichment and job enlargement is practiced in this organization. } \\
\text { ('Job Enrichment' means motivated job performance. 'Job enlargement } \\
\text { means ' enlarging the dimensions of the job.) }\end{array}$ & 12 & 2.916 & 21.026 & $\mathbf{H}_{\mathbf{1}}$ \\
\hline 40 & $\begin{array}{l}\text { The job-rotation helps the development of employees. ('Job rotation' } \\
\text { means changing from one branch to another branch of activities) }\end{array}$ & 12 & 5 & 21.026 & $\mathbf{H}_{\mathbf{1}}$ \\
\hline 41 & Employees do not feel suffocated in this organization & 12 & 2.222 & 21.026 & $\mathbf{H}_{1}$ \\
\hline 42 & $\begin{array}{l}\text { Given an option, the employee will like to rejoin and work in this } \\
\text { organization }\end{array}$ & 12 & 5 & 21.026 & $\mathbf{H}_{1}$ \\
\hline 43 & $\begin{array}{l}\text { The police personnel feel that all their interests are taken care of by the } \\
\text { top management }\end{array}$ & 12 & 2.916 & 21.026 & $\mathbf{H}_{\mathbf{1}}$ \\
\hline 44 & $\begin{array}{l}\text { The police personnel feel that the superiors are not the real hindrance } \\
\text { to their progress }\end{array}$ & 12 & 2.916 & 21.026 & $\mathbf{H}_{\mathbf{1}}$ \\
\hline 45 & $\begin{array}{l}\text { The police personnel feel that a change of top executive will help to } \\
\text { improve their lot }\end{array}$ & 12 & 0.138 & 21.026 & $\mathbf{H}_{1}$ \\
\hline
\end{tabular}

Source: Primary Data 
It is clearly that all the calculated values are less than the table values. Hence accepted $\mathbf{H}_{\mathbf{1}}$, it can infer that there is a significant association in between relationship among police employees and job satisfaction. Except in case of the factors 8, 14, 27, 38, 41 and 42 in table 4.

\section{Findings}

1. Male domination is more in the police department in T.S.

2. The leave policy is not moderated according to the changing work environment.

3. Autocracy in police organization.

4. It is identified that most of the superiors have inferiority complex on subordinates at work place that is reason that most of the superiors and seniors not supporting and helping the subordinates and juniors in their job.

5. Junior police officers are afraid to their seniors to discuss about their professional as well as personal problems.

6. The police stations still do not have even basic amenities such as toilets, rest rooms, mineral water facility, etc.

7. The women police staffs are facing a lot of problems due to lack of basic amenities and most of them are willing to change their professor if they were given a chance.

8. It is identified from the research that there is no sufficient place for parking their personal vehicles in the stations.

9. Most of the female employees are having domination from male in the police stations due to lack of strength.

10. Female respondents are not comfortable to discuss their personal and professional problems because most of their superiors are men.

11. Some police stations are far away from the village/town so it is difficult to communicate in emergency.

12. There is no proper fencing/compound wall around the police station. So, most of the police personnel feel unsafe to work in such environment.

13. Orderly system became major problem for both juniors and subordinators.

14. People in this police system do not have fixed mental impression about each other due to pressure from the superiors.

15. Most of the police personnel are not aware about their welfare schemes and system in the organization.

16. The Job enrichment and Job enlargement practice in this organization done mostly on preferential treatment.

17. Most of the police personnel feel dissatisfaction due to lack of specific working time.

18. All the designations of police personnel are facing problems from their superiors.

19. Most of the police employee does not trust each other. There is lack of trust in the police personnel in each other.

20. From the research it is observed that no social interaction between superior, subordinate and peers.

21. Lack of reward and admire is also one of the reason for weak relationship in the police personnel.

22. Most of the employees are dissatisfied with their work relationship due to lack of humanity in the work environment.

23. There is lacking of human relationship due to inferiority complex among the superiors, subordinates and peers.

24. Implementation of HR practices such as Job Enrichment and Job enlargement are moderate in this organization.

25. Police employees are feeling sad about the Job rotation practice in the organization.

26. It is identified that there is no significant association in the perception on work relationship among police employees in relation to designation (Police Constable) and age group, regarding the top executive believes on police personnel behavioral change.

27. There is a no significant association in the perception of job satisfaction among police employees in relation to designation (Police Constable) and age group for the factor the top executive scouts for talent in the juniors and identify that and develop.

28. National Police Commission Seventh Report - May 1981 given a report on the infrastructure in each and every police station but till it is not up to the report.

29. There is a lacking in continues training to the employees in police department.

30. National Police Commission Fifth Report - November 1980 which highlights Women Police Officers importance in the department is also not fulfilled by the organization.

31. It is observed from the research that there is a direct effect of HRD climate on employee relationship i.e., relationship between superior and subordinates, juniors and seniors and peers groups. 


\section{Recommendations}

1. It is recommended conducting periodical refreshment programs to the employees.

2. They also should concentrate on the yoga class to the employees to overcome job stress.

3. They should develop coordination in between superior and subordinates and juniors and seniors employees through arranging annual programs at every police station once in a year.

4. The research suggests that periodic psychoanalysis should be conducted to the police employees to overcome the frustration that appears by dealing with criminals.

5. It is suggested to conduct seminars and workshops on team building, human relationships, goal setting and self-reliance by experts.

6. The research also recommends displaying quotations and pictures in the police staff rooms to motivate and inspirits to human relations and team work at work place.

7. The department recruitment should be done according to the norms so that there will be no variance in the performance of coping.

8. A special care should be taken for the women employees by allotting the entire essential requirement at work place.

9. There is a necessary to moderate the police stations with good infrastructure and near to the town or villages is also compulsory.

10. It is suggested to develop a decentralization procedure so that the junior and subordinates can easily communicate or share the ideas to their superiors.

11. Research also recommended to set up a good leave system to reduce the dissatisfaction among the employees.

12. It is also suggested to the head of the police station should grant the leaves to the employees on their emergency requirement but not on favoritism.

13. An induction program should conduct to the new employees and a special interaction program is also suggested for the interaction of new employees and existing employees to share their views and experience

14. Women officers should be recruited in much larger numbers than at present, particularly to the ranks of Constables, Head Constables, Assistant Sub-Inspectors and Sub-Inspectors of Police and appoint them not in urban but also in rural areas.

15. It is recommended to post at least $30 \%$ of women employees at each police station to reduce misbehavior of men employee on female criminals.

16. The management of police department also should give equal importance to women employees at work place.

17. It is opinion to implement the modern HRD practices in the police organization to strengthen the human relations.

\section{References}

[1]. C.R. Kothari(2004) Research Methodology Methods and Techniques, New Age International Publications, p233, p242

[2]. Ercikti, Vito, Walsh, Higgins-Major Determinants of Job Satisfaction Among Police Managers (2011) Southwest Journal of Criminal Justice, Vol. 8(1). pp. 98-100.

[3]. Mathur K. M., Police in India problems and Perspectives, Gyan Publishing House, New Delhi, 1991 , p. 279.

[4]. Martins, J.H., Loubster, M., Van Wyk, H. J. 1999 Marketing Research: A South African Approach, Pretoria: Unisa Press

[5]. B. G.Verghese (2011) Police Reform Debates in India, Commonwealth Human Rights Initiative, pp04-50.

[6]. Sen Sankar, Reflections and Remmiscences of Police Officer, Concept Publishing Co., New Delhi, 2006, p.147.

[7]. Sen Sankar, Police Training, Problems and Perspectives, Rawat Publications, New Delhi, p.43.

[8]. Umranikar,J.Y (2009), Police Reforms in India, A sisyphean saga, Ameya Prakashan, Pune, , p.19

[9]. http://bprd.nic.in/writereaddata/linkimages/1645442204-volume\%201.pdf

[10]. www.bprd.nic.in

[11]. http://www.tspolice.gov.in

[12]. http://www.mha.nic.in/ 